\title{
Correspondence
}

\section{Spectacle prescribing among 10-year-old children}

SIR, Your editorial in the December issue of the $B J O$ uses my paper ${ }^{1}$ to draw inferences which the data published in it cannot support. The data do strongly suggest that overprescribing of spectacles is common in children but provide no information on who was responsible for these prescriptions.

You imply that the cause is entirely prescribing by opticians to children with medical problems such as headaches. Although the latter were more common among children with questionable prescriptions, they were actually reported by less than $20 \%$. Treatment of headaches is therefore an unlikely explanation for more than a small proportion of questionable prescriptions.

We do not know what proportion of children were treated by opticians and what proportion by doctors in eye clinics. Both of these groups see children and both could have been responsible for the observed overprescribing.

Department of Child Health, SARAH STEWART-BROWN Royal Hospital for Sick Children, 65 St Michael's Hill,

Bristol BS2 8DZ

\section{Reference}

1 Stewart-Brown S. Spectacle prescribing among 10-year-old children. Br J Ophthalmol 1985; 69: 874-80.

${ }_{*}^{* *}$ We agree with Dr Stewart-Brown that her paper gives no information as to who was responsible for the spectacle prescriptions. Our editorial note contains the phrase 'if we assume that the proportions conform to the national average, it would be likely that $80-90 \%$ of the prescriptions would have been issued by non-medically qualified persons.' Furthermore, we certainly do not assume that all the unnecessary prescriptions were given for headache, and we mention no less than seven other possibilities. However, we accept that a cursory reading of the editorial could give the impression that Dr Stewart-Brown's paper had pinpointed headache as the principal cause of the over-prescribing, and we hasten to agree with her that such was not neccessarily the case.-EDITOR.

\section{Defective vision in children}

SIR, I read with interest the papers by $\mathbf{R} \mathbf{M}$ Ingram and colleagues, ' ' which proved useful additions to the literature. However, the interpretations made in the second paper ${ }^{2}$ with regard to the success of occlusion are somewhat narrow. It would seem that the results are said not to be encouraging because final acuity is not $6 / 6$. Despite this assertion, the average improvement is virtually two Snellen lines and the maximum benefit five lines (using an interpre- tation which takes the pessimistic view that an improvement from $<6 / 60$ to $6 / 60$ is equivalent to a single line's improvement).

If it is accepted that there is an innate variation in visual capability among normals, that the Snellen chart is an irregularly progressive assessment of acuity, and that an improvement in acuity of only one line may be of visual significance in some cases, then I would submit that the results submitted are moderately encouraging. This evaluation of the results does not of course negate the argument that a better response might be achieved with screening and management before the end of the first year of life. London Refraction Hospital, 56-62 Newington Causeway, K H EDWARDS, Secretary London SE1 6DR

\section{References}

1 Ingram RM, Walker C, Wilson JM, Arnold PE, Dally S. Prediction of amblyopia and squint by mcans of refraction at age 1 year. BrJ Ophthalmol 1986; 70: 12-5.

2 Ingram RM, Walker C, Wilson JM, Arnold PE, Dally S. Screcning for visual defects in preschool children. BrJOphthalmol 1986: 70: 16-21

SIR, Certainly there was some improvement in the acuity of children identified as having defective vision at $31 / 2$, but the real question is whether it was more than it would have been if they had not been identified until 5 years of age (under present arrangements for vision screening at school). Until this has been clearly demonstrated, there is no reason either to institute a new (additional) screening test or to change the present arrangements. Indeed it could be disadvantageous to do so.'

Kettering and District General Hospital,

R M INGRAM

Rothwell Road,

Kettering NN16 8UZ

\section{Reference}

1 Ingram RM. Should preschool children be screcned for visual defects? Trans Ophthalmol Soc UK 1985; 104: 646-7.

\section{Obituary}

\section{A. J. Boase, CMG, OBE, FRCS, $L R C P, D O M S$}

Mr Arthur Joseph Boase, formerly ophthalmic surgeon in Uganda and later in Jerusalem, died peacefully on 31 January 1986 aged 84 years.

Arthur Boase was born in British Guiana, where his father was a medical officer. He was educated at Mount 